\title{
Lack of Plasma Membrane Targeting of a G172D Mutant Thiamine Transporter Derived from Rogers Syndrome Family
}

\author{
Dana Baron, ${ }^{1}$ Yehuda G. Assaraf, ${ }^{2}$ Nadine Cohen, ${ }^{1}$ and Ami Aronheim ${ }^{1}$ \\ ${ }^{1}$ Department of Molecular Genetics, the Rappaport Institute for Research in the Medical Sciences and the \\ B. Rappaport Faculty of Medicine, The Technion-Israel Institute of Technology, Haifa, Israel \\ ${ }^{2}$ Department of Biology, The Technion-Israel Institute of Technology, Haifa, Israel \\ Accepted June 28, 2002
}

\begin{abstract}
Background: Rogers syndrome, also known as thiamine responsive megaloblastic anemia (TRMA), is an autosomal recessive disorder resulting in megaloblastic anemia, diabetes mellitus and sensorineural deafness. The gene associated with Rogers syndrome encodes for a plasma membrane thiamine transporter, THTR-1, a member of the solute carrier family that includes its homologue THTR-2 and the reduced folate carrier.

Materials and Methods: Using transient expression of wild-type and a missense mutant THTR-1 protein, derived from a TRMA family, in different cell lines and immunodetection analysis, we determined the expression, posttranslational modification, and subcellular localization of the wild-type and G172D mutant THTR-1. The transport activity of the transfected THTR-1 proteins was measured using a $\left[{ }^{3} \mathrm{H}\right]$ thiamine uptake assay.

Results: The mutant THTR-1 protein was undetectable in transfected cells grown at $37^{\circ} \mathrm{C}$ but was readily expressed in transfected cells cultured at $28^{\circ} \mathrm{C}$, thereby allowing for further biochemical and functional analysis.
\end{abstract}

In contrast to its fully glycosylated wild-type mature protein, the mutant THTR-1 protein underwent only the initial stage of $N$-linked glycosylation. The failure to undergo a complete glycosylation resulted in the lack of plasma membrane targeting and confinement of the mutant THTR-1 to the Golgi and endoplasmic reticulum (ER) compartment. Consistently, either treatment with tunicamycin or substitution of the THTR-1 consensus $\mathrm{N}$-glycosylation acceptor asparagine 63 with glutamine, abolished its glycosylation and plasma membrane targeting.

Conclusions: Taken collectively, these results suggest that the G172D mutation presumably misfolded THTR-1 protein that fails to undergo a complete glycosylation, is retained in the Golgi-ER compartment and thereby cannot be targeted to the plasma membrane. Finally, transfection studies revealed that the mutant G172D THTR-1 failed to transport thiamine. This is the first molecular and functional characterization of a missense mutant THTR-1 derived from a family with Rogers syndrome.

\section{Introduction}

Thiamine is the precursor for thiamine pyrophosphate, a coenzyme required for the activity of transketolase and the pyruvate dehydrogenase complexes, $\alpha$-ketoglutarate and branched-chain keto acids (1). Thiamine is an essential vitamin in the diet; the main sources are fresh fruits and vegetables. At low thiamine concentrations, thiamine is transported into the cell via saturable active transport systems, THTR-1 (2-5) and THTR-2 (6). However, at high thiamine concentrations, it is presumably transported through a passive diffusion process (7). Transient thiamine deficiency states can result in

Current address for N. C.: R. W. Johnson Pharmaceutical Research Institute, Department of Pharmacogenomics, Raritan, New Jersey, 08869, USA.

Co-correspondence and reprint requests should be addressed to: A. Aronheim, Department of Molecular Genetics, The B. Rappaport Faculty of Medicine, 7 Efron St. Bat Galim, The Technion-Israel Institute of Technology, Haifa, Israel 31096. Phone: 9724 8295226; fax: 9724 8295225; e-mail: aronheim@tx.technion.ac.il. and

Y. G. Assaraf, Department of Biology, The Technion Haifa 32000, Israel. Phone: 972-4-8293744; fax: 972-4-8225153;

e-mail: assaraf@tx.technion.ac.il heart and neurologic defects such as in BeriBeri disease and Wernike-Korsakoff syndrome.

Thiamine-responsive megaloblastic anemia TRMA also known as Rogers syndrome, is an earlyonset autosomal recessive disorder defined by the occurrence of megaloblastic anemia, diabetes mellitus, and sensorineural deafness (TRMA; OMIM 249270) (8). Patients carrying this disorder respond in varying degrees to thiamine supplementation (8), suggesting that active thiamine transport is impaired (8-10). Following prolonged thiamine treatment protocols, patients develop insulin-dependent type II diabetes (11).

The gene responsible for TRMA was identified by positional cloning (2-5). The gene identified, SLC19A2, encodes for a thiamine transporter (THTR-1), a member of the solute carrier family consisting of its homolog THTR-2 (SLC19A3) $(6,12)$ and the reduced folate carrier RFCl (13-15). RFCl encodes for a transporter responsible for the uptake of reduced folate cofactors that are essential for the de novo biosynthesis of purines and thymidylate and is the primary transporter for folate-based chemotherapeutic drugs, including methotrexate (16). The human THTR-1 gene 
encodes for a 497-amino acid protein containing 10-12 putative transmembrane domains (2-4). THTR-1 is responsible for thiamine transport in $\mathrm{a} \mathrm{Na}^{+}$independent manner. THTR-1-mediated thiamine transport is stimulated by a $\mathrm{H}^{+}$efflux gradient (5).

Recently it was found that the p53 transcription factor regulates thiamine homeostasis via THTR-1 transcription (17). In patients with Rogers syndrome, the THTR-1 gene was found to be mutated in 17 families $(2,18)$. In this respect Rindi et al. (10), measured thiamine transport from healthy controls and patients with Rogers syndrome and observed that, unlike with healthy erythrocytes, red blood cells derived from Rogers syndrome patients failed to exhibit thiamine transport. Consistently, Stagg et al. (19) demonstrated that fibroblasts isolated from Rogers syndrome patients take up only $\sim 5-10 \%$ of thiamine as compared with fibroblasts derived from healthy individuals. This uptake occurred via an apparently low-affinity, unsaturable thiamine route. These results were compatible with an entry of thiamine via passive diffusion and may explain the fact that megadoses of thiamine are necessary to achieve minimally sufficient thiamine levels in Rogers syndrome patients. Thus, high doses of thiamine serve in the treatment of Rogers syndrome patients.

The molecular basis underlying Rogers syndrome frequently results from the lack of thiamine transporter expression due to premature translation termination mutations (18). However, three missense mutations were also identified, resulting in single amino acid substitutions. Here we describe the molecular consequences of a single amino acid substitution identified in an Italian Rogers syndrome family harboring a glycine to aspartate substitution at position 172 of THTR-1. Although the cDNA is properly transcribed and translated in vitro, no protein could be detected in NIH3T3 cells transfected with the mutant G172D THTR-1 cultured at $37^{\circ} \mathrm{C}$. Shifting transfected cells to $28^{\circ} \mathrm{C}$ resulted in a substantial expression of the mutant G172D THTR-1 protein, thereby allowing for biochemical and functional characterization. The present study establishes the role of $N$-glycosylation in THTR-1 plasma membrane localization and function and identifies asparagine 63 as the major $N$-glycosylation site responsible for THTR-1 membrane localization. This study constitutes the first molecular characterization of a missense mutant THTR-1 protein derived from a TRMA family.

\section{Materials and Methods} Cell Cultures

NIH3T3 and Swiss 3T3 cells were cultured under monolayer conditions in a humidified atmosphere of $5 \% \mathrm{CO}_{2}$ at $37^{\circ} \mathrm{C}$ (unless otherwise indicated). Cells were grown in DMEM-based media containing $10 \%$ FCS, $2 \mathrm{mM}$ L-glutamine, 100 units/ml penicillin, and $100 \mu \mathrm{g} / \mathrm{ml}$ streptomycin.

\section{Cell Transfection}

NIH3T3 cell transfections were carried out in $60 \mathrm{~mm}$ plates using LipofectAMINE reagent (Invitrogen Inc., Carlsbad, CA, USA), and XtremeGENE reagent (Roche Inc., Mannheim, Germany) was used for Swiss 3T3 cells. Typically, for NIH3T3 cell transfections, $6 \mu \mathrm{g}$ of plasmid DNA were used with $9 \mu$ l of the Lipofect AMINE reagent whereas for Swiss 3T3 cells, $2 \mu \mathrm{g}$ of plasmid DNA were used with $10 \mu \mathrm{l}$ of XtremeGENE reagent according to the manufacturer instructions.

\section{Retrovirus Production and Infection}

Retroviruses expressing the different proteins were generated by transfection of retroviral vectors and an expression vector of VSVG into viral packaging cells 293gp expressing the gag and pol genes (20). The medium of transfected 293gp cells containing retroviruses was used to infect Swiss 3T3 cells with either wild-type THTR-1 or mutant G172D THTR-1 expressing retroviruses. Forty-eight hr after infection, puromycin $(3 \mu \mathrm{g} / \mathrm{ml})$ was added and resistant cells were pooled 1 week later.

\section{Cell Extract}

Whole cell extracts were isolated as previously described (21).

\section{Isolation of THTR-1 cDNA}

A reverse transcription polymerase chain reaction (RT-PCR) was used to isolate the cDNA from human RNA. RNA was isolated from human fibroblasts using a total mRNA isolation kit (Boehringer Manheim Ltd., Ingelheim, Germany). Sequence analysis verified that the human THTR-1 CDNA was free of PCR mutations.

\section{Mammalian Expression Plasmids}

pCan is a pCDNA-based (Invitrogen Inc., Carlsbad, CA, USA) mammalian expression vector expressing proteins downstream of a Myc-epitope tag. Protein expression is under the control of cytomegalovirus (CMV) immediate early promoter. An oligoncleotidebased PCR approach was used to amplify the human THTR-1 cDNA that was fused, in frame, with the Myc-epitope tag using 5'-EcoRI and 3'-XhoI restriction sites. The Myc tag and polylinker region are composed of the following 18 amino acids: MVQKLISEEDLRIHRCR.

The pCL-Babe expression vector (20) expressing the THTR-1 wild-type and the G172D mutant was constructed by insertion of the Myc-THTR-1 cDNA fragment. The fragment was excised from pCan expression vector by HinDIII fill-in followed by XhoI restriction and inserted into BamHI fill-in Sal I linearized vector. The pCL-Babe expression vector facilitates the rapid establishment of stably expressing THTR-1 cell lines using retrovirus infection.

Green lantern expression plasmid was used (Invitrogen Inc., Carlsbad, CA, USA). The plasmid encodes for the green fluorescent protein under the control of the CMV promoter. 
A pcDNA3-based expression plasmid (Invitrogen Inc.) encoding for the human RFC fused to hemagglutinin (HA) peptide epitope as described (22).

\section{Site-directed Mutagenesis}

The corresponding oligonucleotides were designed to yield an aspartate 172 for glycine substitution and to generate an AatII restriction site. This resulted in the conversion of serine 173 to a valine residue. Sitedrected mutagenesis was performed using the QuikChange XL site directed mutagenesis kit according to the manufacturer instructions (Stratagene Inc., La Jolla, CA, USA) with the appropriate primers.

\section{Upstream oligo: GGGCTTTACAGTCGACGTCGTC-} CTAGGGCAAATCC

Downstream oligo: GGATTTGCCCTAGGACGACGTCCACTGTAAAGCCC.

To obtain an array of amino acid substitutions at glycine 172, the following degenerate oligonucleotides were designed to generate multiple changes at position 172. This resulted in the loss of the artificially inserted AatII restriction site, thereby leading to the resubstitution of the inserted valine residue at position 173 for a native serine residue.

Upstream oligo: GGGCTTTACAGTGRHNTCTGTCCTAGGGCAAATCC

Downstream oligo: GGATTTGCCCTAGGACAGANDYCACTGTAAAGCCC.

All analyses with THTR-1 mutants were performed with a single amino acid substitution at position 172. Asparagine 63 mutation was performed by a PCR approach using specific primers that resulted in the introduction of a MfeI restriction site. Inserted mutations were confirmed by DNA sequencing.

Upstream oligo: CGCGCGCAATTGACCGAGAGGGAGGTCTTCAA

Downstream oligo: CTTCTCGCAATTGCTTGTCCGGCCCCAGCAG

In Vitro Translation

Coupled in vitro transcription and translation were performed using the T7 TNT quick transcription translation kit according to the manufacturer instructions (Promega Inc., Madison, WI, USA).

\section{Tunicamycin Treatment}

Tunicamycin (Sigma Cat\# T7765) was dissolved in dimethyl sulfoxide to yield a stock solution of $10 \mathrm{mg} / \mathrm{ml}$. This $N$-glycosylation inhibitor was applied to monolayer cells at $10 \mu \mathrm{g} / \mathrm{ml}$ for $24 \mathrm{hr}$ prior to cell harvesting or immunofluorescent staining.

\section{Peptide N-Glycosidase F (PNGase F) Treatment}

Cell extracts $(50 \mu \mathrm{g})$ were incubated with denaturing buffer containing sodium phosphate $\mathrm{pH}$ 7.5,
$0.5 \%$ SDS, and $1 \% \beta$-mercaptoethanol in the presence or absence of 2000 units of PNGase F (NEB Inc., Beverly, MA, USA) for $45 \mathrm{~min}$ at $37^{\circ} \mathrm{C}$.

\section{SDS-PAGE and Western Blotting}

Protein cell lysates $(50 \mu \mathrm{g})$ or $5 \mu \mathrm{l}$ of a programmed rabbit reticulocyte lysate were resolved on a $10 \%$ SDS-PAGE followed by immobilization onto Hybond nitrocellulose membrane (Amersham Inc., Piscataway, NJ, USA). Western blots were then blocked with a buffer containing $10 \%$ low-fat milk in PBS for $\mathrm{l} \mathrm{hr}$ and incubated with anti-Myc 9E1l monoclonal antibody (Babco Ltd., Piscataway, NJ, USA, Cat\# MMS-150R) followed by a secondary goat anti-mouse antibody conjugated to horse radish peroxidase (HRP). Detection was performed with a chemiluminescent substrate (SuperSignal, Pierce Inc., Iselin, NJ, USA) and membranes were exposed to $x$-ray film and autoradiography.

\section{Immunofluorescence}

Swiss 3 T3 cells were grown on 22-mm coverslips and transfected as described. Forty-eight hours after transfection, cells were fixed for $10 \mathrm{~min}$ in $3.7 \%$ formaldehyde in PBS. Following two washes with PBS, cells were incubated for $5 \mathrm{~min}$ in PBS containing $0.1 \%$ Triton X-100. Thereafter, coverslips were incubated for 30 min with blocking buffer containing 3\% FCS and $3 \%$ BSA in PBS, followed by three washes with PBS. Subsequently, primary anti-Myc 9E11 monoclonal antibody was applied for $1 \mathrm{hr}$ in PBS containing $1 \%$ FCS. Cells were washed with PBS and CY3-conjugated goat anti-mouse antibody (Jackson 115-165-100) was applied at a dilution of 1:250 in PBS buffer containing $2 \%$ BSA, 2\% normal goat serum (Jackson 005-000121 ), and $0.1 \%$ Tween-20, followed by three washes in PBS and applied onto glass slides with fluoromount-G. Confocal laser scanning microscopy was carried out using a Bio-Rad microscope (Hercules, CA, USA). Each coverslip contained at least $5 \times 10^{4}$ cells and efficiency of transfection varied between 10 and $20 \%$. About $90 \%$ of transfected cells exhibited red and green staining and all of these cells displayed the staining presented. We have analyzed at least 100 transfected cells from each transfection slide. The staining analysis was repeated in five independent transfection experiments showing identical staining patterns.

\section{Assay of Thiamine Uptake}

Swiss 3T3 cells stably transfected with wild-type THTR-1, mutant G172D THTR-1, and vector control were trypsinized $2 \mathrm{hr}$ prior to thiamine transport measurements. Cells were incubated in a $15-\mathrm{ml}$ tube (Greiner Ltd., Frickenhausen, Germany) at a density of $3 \times 10^{5}$ cells $/ \mathrm{ml}$ in a serum-free DMEM medium lacking thiamine. Swiss 3T3 cells were sedimented by centrifugation and resuspended in $50 \mu \mathrm{l}$ of transport buffer containing $0.6 \mu \mathrm{M}$ of $\left[{ }^{3} \mathrm{H}\right]$-thiamine (30 ci/mmol; Amersham) for $20 \mathrm{~min}$ at $37^{\circ} \mathrm{C}$ as previously described (5). Cells were then washed twice 
with $10 \mathrm{ml}$ ice-cold PBS. Cells were then lysed with $0.1 \mathrm{ml}$ of $0.2 \mathrm{M} \mathrm{NaOH}$ at $65^{\circ} \mathrm{C}$ for $30 \mathrm{~min}$ (23). The lysate was used to determine intracellular radioactivity in a liquid scintillation spectrometer.

\section{Accession Numbers}

The amino acid sequence of the corresponding GeneBank accession numbers were analyzed by scan prosite alignment: Mouse RFCl-AAC53287; Hamster RFC1-P42557; Human RFC1-U19720; Rat RFCl-NM_017299; Human THTR-2-NP_079519; Mouse THTR-2-AAG53880; Human THTR-1AF135488; Mouse THTR-1-AF2 16204.

\section{Results}

Expression of Wild-Type and Mutant G172D Human THTR-1 in Murine NIH3T3 Cells

We used a transient transfection assay in NIH3T3 cells to express human THTR-1 cDNA harboring an $\mathrm{N}$-terminus Myc tag. The expression of THTR-1 was detected by Western blot analysis using anti-Myc $9 \mathrm{E} 11$ monoclonal antibodies. A strong signal was detected in extracts derived from cells transfected with the wild-type THTR-1 cDNA. The band obtained corresponded to a broadly migrating protein with an average molecular mass of $\sim 68 \mathrm{kDa}$ (Fig. 1A lane 2). The calculated core molecular mass of the THTR- 1 is $55.4 \mathrm{kDa}$, whereas the observed core molecular mass of the in vitro translated THTR-1 was $52 \mathrm{kDa}$ (Fig. 1B lane 2). The increased electrophoretic mobility of some hydrophobic transmembrane proteins is well established. We hypothesized that the slower and broadly migrating protein species (Fig. 1A lane 2) may correspond to varying degrees of $N$-linked glycosylation that is typical to the vast majority of integral plasma membrane proteins (24).

To characterize the functional consequences of the missense mutation occurring in an Italian TRMA family (2), we used site-directed mutagenesis to convert the glycine 172 residue to aspartate (G172D). Transfection of the mutant G172D THTR-1 cDNA into NIH 3T3 followed by total cellular protein extraction, SDS gel electrophoresis, and Western blotting indicated that the mutant G172D THTR-1 protein was undetectable (Fig. IA lane 3). To verify that the G172D THTR-1 expression plasmid can be properly transcribed and translated, we used an in vitro translation system (rabbit reticulocyte lysate) in the presence of $\left[{ }^{35} \mathrm{~S}\right]$-methionine. In vitro translated, radiolabeled protein(s) were then resolved on SDS-PAGE (Fig. 1B). Both the mutant G172D and the wild-type THTR-1 proteins were efficiently transcribed and translated resulting in a sharp protein band of $52 \mathrm{kDa}$ (Fig. 1B).

\section{G172D THTR-1 Mutation Results}

in a Temperature-Sensitive Protein

Previous studies with human CFTR have shown that protein expression was absent at $37^{\circ} \mathrm{C}$, but present at substantial levels at a temperature lower than
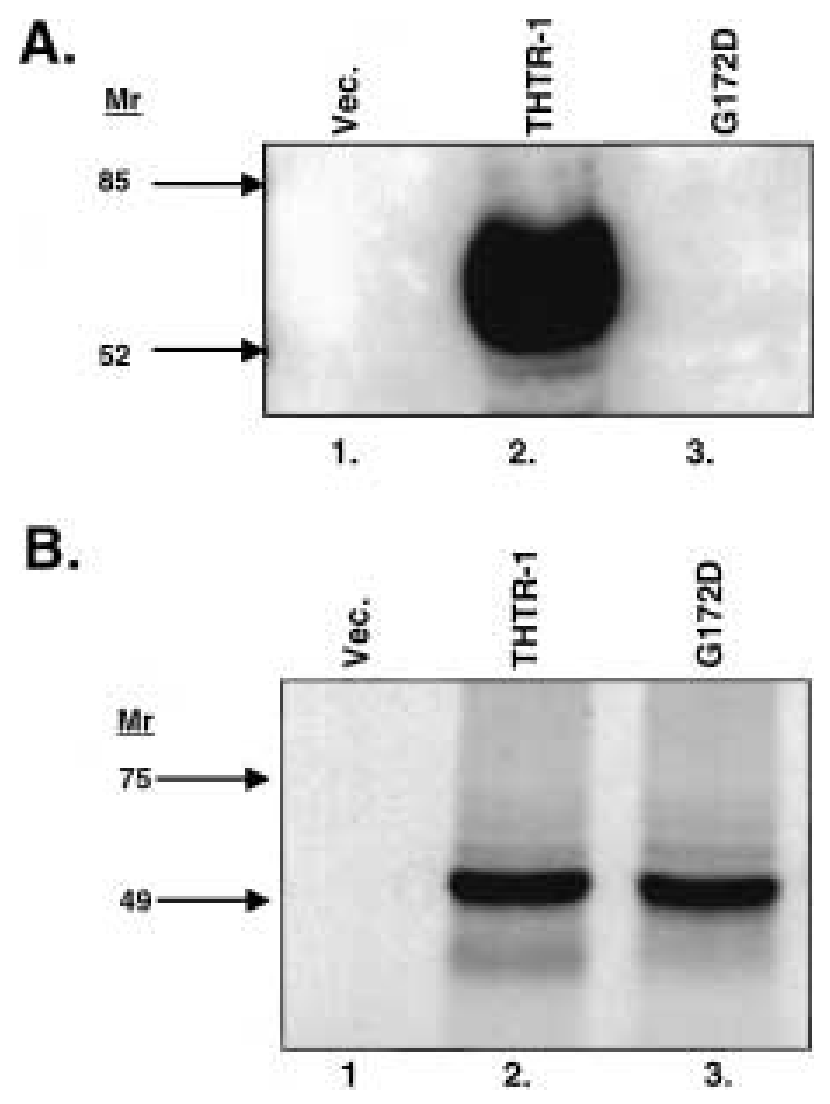

Fig. 1. THTR-1 expression in NIH3T3 cells transfected with the wild-type or the mutant G172D THTR-1 expression plasmids. (A) NIH 3 T3 cells were transiently transfected with either a wild-type Myc-THTR-1 expression plasmid (THTR) or a mutant Myc-THTR-1 expression plasmid in which glycine 172 was substituted by an aspartic acid (THTR G172D). Cells transfected with an empty pCan expression vector (Vec.) were used as controls. Total cell lysates were prepared and proteins were resolved on a $10 \%$ SDS-PAGE followed by Western blotting using an anti-Myc 9E11 monoclonal antibody and anti-mouse IgG conjugated to HRP (Santa Cruz Inc., Santa Cruz, CA, USA) followed by chemiluminescence detection. Molecular weight (Mr) markers (ProSieve, BioWhittaker Molecular Applications Inc., Santa Cruz, CA, USA) are shown in $\mathrm{kDa}$. (B) The indicated expression plasmids were used in a coupled in vitro transcription-translation kit using the T7 RNA polymerase in the presence of $\left[{ }^{35} \mathrm{~S}\right]$-methionine. Proteins were then resolved on $10 \%$ SDS-PAGE followed by autoradiography.

$30^{\circ} \mathrm{C}(25)$. Thus, we assessed whether or not the expression of the G172D mutant THTR-1 protein can be detected at a lower temperature. We transfected NIH 3T3 cells with different expression plasmids encoding for both wild-type and G172D mutant THTR-1 and cultured the cells at $28^{\circ} \mathrm{C}$. Cell extracts derived from transfected cells were subjected to SDS-PAGE and Western blot analysis using anti-Myc 9E11 monoclonal antibodies (Fig. 2A). Surprisingly, the mutant G172D THTR-1 was expressed at substantial levels when cells were cultured at $28^{\circ} \mathrm{C}$ (Fig. $2 \mathrm{~A}$ lane 3). In addition, the protein was detected as a sharp band migrating $\sim 2-3 \mathrm{kDa}$ slower than the $52-\mathrm{kDa}$ in vitro translated THTR-1 protein (Fig. 2A, compare lanes 3 and 5). 

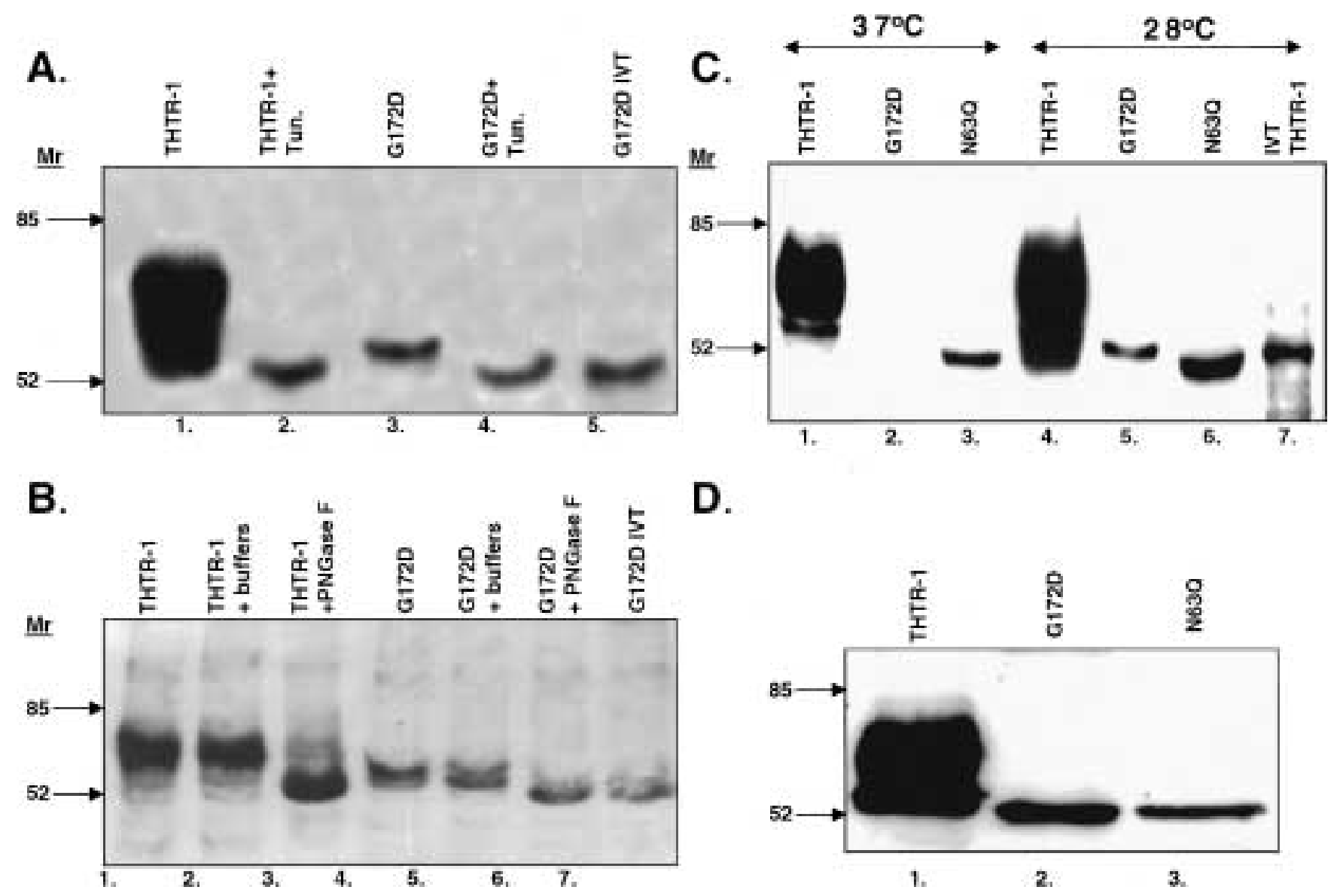

Fig. 2. THTR-1 protein is $\mathrm{N}$-glycosylated on asparagine 63. (A) NIH3T3 cells were transfected as described in Figure 1 legend, except that after transfection, cells were incubated at $28^{\circ} \mathrm{C}$ for $40 \mathrm{hr}$. Cell lysates were prepared and proteins were resolved on a $10 \%$ SDS-PAGE and THTR-1 expression was followed as described in Figure 1. Where indicated, cells were treated with tunicamycin $(10 \mu \mathrm{g} / \mathrm{ml})$ for $24 \mathrm{hr}$ prior to cell harvesting. [ $\mathrm{S}^{35}$ ]-methionine-labeled THTR-1 G172D in vitro translated protein product (G172D IVT) represents the migration of the core THTR-1 protein with no posttranslational modifications (lane 5). (B) Cell lysates (50 $\mu \mathrm{g}$ protein) derived from THTR-1-transfected cells either with the wild-type (THTR) or mutant G172D THTR-1 expression plasmids, as indicated, was incubated for $45 \mathrm{~min}$ at $37^{\circ} \mathrm{C}$ in the absence (+buffer) or presence of 2000 units of PNGase F (+PNGase F). Following PNGase F treatment, SDS-sample buffer was added and the extract was subjected to $10 \%$ SDS-PAGE followed by Western blotting. In vitro translated product (G172D IVT) represents the migration of the core unglycosylated THTR-1 protein (lane 7). (C). NIH3T3 cells were transfected with different expression plasmids encoding for wild-type THTR-1 and the indicated mutants. Transfected cells were grown at either $37^{\circ} \mathrm{C}$ (lanes 1-3) or $28^{\circ} \mathrm{C}$ (lanes 4-6) and proteins from in vitro THTR-1 translated product (lane 7) were separated by SDS-PAGE followed by Western blotting with anti-Myc 9E11 monoclonal antibody. (D) Swiss 3T3 cells were transfected with different expression plasmids encoding for wild-type THTR-1 and the indicated mutants grown at $28^{\circ} \mathrm{C}$. Cell lysate and Western blotting were performed as described in (A).

\section{The Mutant G172D THTR-1 Is Incompletely $N$-Glycosylated}

To test whether or not the slightly slower migration of the G172D THTR-1 mutant is due to an incomplete $N$-glycosylation, we treated THTR-1 cDNA-transfected NIH3T3 cells with $10 \mu \mathrm{g} / \mathrm{ml}$ tunicamycin, an established inhibitor of $N$-linked glycosylation. Cell extracts derived from the wild-type THTR-1-transfected cells treated with tunicamycin exhibited an identical migration pattern as compared with the in vitro translated 52-kDa THTR-1 protein (Fig. 2A, compare lane 2 with lane 5). Similarly, cell extracts derived from the mutant G172D THTR-1-transfected cells treated with tunicamycin also exhibited an identical migration pattern of $52 \mathrm{kDa}$ as observed with the wild-type unglycosylated protein (Fig. 2A, compare lanes 2 and $4)$, as obtained with the in vitro translated wild-type THTR-1 (Fig. 1B) and mutant G172D THTR-1 cDNA (Fig. 1B and Fig. 2A). These results suggest that the mature wild-type THTR-1 protein undergoes a complete $N$-glycosylation that adds $\sim 16 \mathrm{kDa}$ to its molecular mass, whereas the mutant G172D gains only 2-3 $\mathrm{kDa}$. To assess whether $\mathrm{N}$-glycosylation is the only post-translational modification responsible for the markedly decreased migration of the transfected THTR-1 protein, we used peptide $N$-glycosidase F (PNGase F). PNGase F cleaves the covalent bond between the innermost $N$-acetyl-D-glucosamine and the acceptor asparagine residue, thereby resulting in the complete removal of the $\mathrm{N}$-glycan from glycosylated 
proteins. Total cell extract derived from transfected cells treated with PNGase F exhibited a complete removal of the carbohydrate, resulting in a sharp 52-kDa protein band with an identical electrophoretic migration for both the core wild-type THTR-1 protein and the in vitro translated mutant G172D THTR-1 protein (Fig. 2 B). These results strongly suggest that the slower migration of the mature wild-type THTR-1 protein is due to $\mathrm{N}$-glycosylation and that the mutant
G172D THTR-1 undergoes only the initial stage of glycosylation.

Human THTR- 1 and THTR-2 contain a conserved $\mathrm{N}$-linked glycosylation site (Asn-X-Ser/Thr) at asparagine 63 (6) (Table 1A). In order to directly asses whether $\mathrm{N}$-glycosylation of the acceptor asparagine 63 is the post-translational modification leading to the slower electrophoretic mobility of the wildtype and G172D mutant THTR-1 proteins, we used

Table 1. Sequence comparison of various members of the solute carrier family

\begin{tabular}{|c|c|c|c|c|c|}
\hline \multirow[t]{25}{*}{ A. } & $\begin{array}{l}\text { THTR-1 } \\
N \text {-glycosylation } \\
\text { Consensus Site }\end{array}$ & $\begin{array}{l}\text { Family } \\
\text { Member }\end{array}$ & $\begin{array}{l}\text { a.a. } \\
\text { Position }\end{array}$ & $\begin{array}{c}N \text {-glycosylation } \\
\text { Sequence }\end{array}$ & Domain \\
\hline & \multirow[t]{8}{*}{ N63 (63-65) } & hTHTR-1 & $59-70$ & GPDKNLTEREVF & \multirow[t]{8}{*}{ Extracellular loop 2 (EL2) } \\
\hline & & mTHTR-1 & $59-70$ & GPDKNLTERQVY & \\
\hline & & hTHTR-2 & $41-52$ & GPDKNLTSAEIT & \\
\hline & & mTHTR-2 & $42-53$ & EPSKNLTSPEMT & \\
\hline & & haRFCl & $52-63$ & LLQQNFTIEQVT & \\
\hline & & hRFCl & $54-65$ & GPDKNFTREQVT & \\
\hline & & mRFCl & $52-63$ & LLERKFTKEQVT & \\
\hline & & rRFC-1 & $52-63$ & LLERNFTKEQVT & \\
\hline & \multirow[t]{8}{*}{ N314 (314-316) } & hTHTR-1 & $311-322$ & QVVNNYTQGLWE & \multirow{8}{*}{$\begin{array}{l}\text { Transmembrane } \\
\text { domain } 7 \text { (TMD7) }\end{array}$} \\
\hline & & mTHTR-1 & $311-322$ & FQVVNYAQGLWE & \\
\hline & & hTHTR-2 & $293-304$ & NQVLNYVQILWD & \\
\hline & & mTHTR-2 & $287-298$ & NQILNYVQVLWE & \\
\hline & & haRFCl & $284-295$ & YLIVYYVHVLWS & \\
\hline & & hRFCl & $282-293$ & YLVVYYVHILWN & \\
\hline & & mRFCl & $282-293$ & YLITYYVHVLWR & \\
\hline & & rRFC-1 & $285-296$ & YLITYYVHVLWL & \\
\hline & \multirow[t]{8}{*}{ N413 (413-415) } & hTHTR-1 & $410-421$ & QIAANLSMERYA & \multirow{8}{*}{$\begin{array}{c}\text { Transmembrane } \\
\text { domain } 10 \text { (TMD 10) }\end{array}$} \\
\hline & & mTHTR-1 & $411-422$ & QIAANLSMERYA & \\
\hline & & hTHTR-2 & $393-404$ & QIAVNLNVERYA & \\
\hline & & mTHTR-2 & $387-398$ & QIAVNLSLERYA & \\
\hline & & haRFCl & $386-397$ & QIASSLSKELCA & \\
\hline & & hRFCl & $386-397$ & QIASSLSKELCA & \\
\hline & & mRFCl & $379-390$ & QIASSLSKELCA & \\
\hline & & rRFC-1 & $379-390$ & QIASSLSKELCA & \\
\hline \multirow[t]{9}{*}{ B. } & & $\begin{array}{l}\text { Family } \\
\text { Member }\end{array}$ & $\begin{array}{l}\text { a.a. } \\
\text { Position }\end{array}$ & TMD5 & \\
\hline & & hTHTR-1 & $165-186$ & \multicolumn{2}{|c|}{ TLVGFTVGSVLGQILVSVAGWS } \\
\hline & & mTHTR-1 & $165-186$ & \multicolumn{2}{|c|}{ TLVGFTVGSVLGGILVSVVGWS } \\
\hline & & hTHTR-2 & $147-168$ & \multicolumn{2}{|c|}{ TLAAYTAGSVLAQLLVSLANMS } \\
\hline & & mTHTR-2 & $148-169$ & \multicolumn{2}{|c|}{ TLVAYTAGSVLAQLLVSLTNLP } \\
\hline & & haRFCl & $158-179$ & \multicolumn{2}{|c|}{ VLLGVFTSSVLGQVLWPLEQKS } \\
\hline & & hRFCl & $159-180$ & \multicolumn{2}{|c|}{ VLLGVFTSSVLGQLLVTVGRVS } \\
\hline & & mRFCl & $158-179$ & \multicolumn{2}{|c|}{ VLLGVFISSVLGQALVTVGHIS } \\
\hline & & rRFCl & $158-179$ & \multicolumn{2}{|c|}{ VLLGVFISSVLGQVLVTLGGIS } \\
\hline
\end{tabular}

(A) Sequence comparison of the putative THTR-1 N-glycosylation consensus sites (Asn-X-Ser/Thr) based on scan prosite analysis with various members of the solute carrier family. The conserved consensus motif (NXT) are indicated by light shading. Transmembrane topology is based on Diaz et al. 1999 [4]. The asparagine 63 and 46 of THTR-1 and THTR-2 respectively are indicated in bold. (B) Amino acid alignment of the glycine 172 human THTR-1 vicinity in TMD5 of the various members of the solute carrier family. The conserved glycine 172 and 154 in THTR-1 and THTR-2 respectively are indicated in bold. Light shading indicates the amino acids showing conservation in all members of the solute carrier family. 
site-directed mutagenesis to substitute asparagine 63 with glutamine (N63Q). Cell extract derived from NIH3T3 cells transfected with plasmids encoding for the mutant N63Q THTR-1 was resolved on $10 \%$ SDS-PAGE followed by Western blot analysis with anti-myc 9E11 monoclonal antibody (Fig. 2C). Mutant N63Q THTR-1 was efficiently expressed both at $37^{\circ} \mathrm{C}$ (Fig. 2C lane 3) and $28^{\circ} \mathrm{C}$ (Fig. 2C lane 6) and exhibited an identical electrophoretic mobility of $52 \mathrm{kDa}$ as compared with both the in vitro translated wild-type and mutant GI72D THTR-1 proteins (Fig. 2C). Similar expression pattern of the THTR-1 proteins were observed in the Swiss 3T3 infected cell line (Fig. 2D) as compared with NIH 3 T3 cells grown at $28^{\circ} \mathrm{C}$ (Fig. 2C). Hence, these results confirm that the conserved asparagine 63 is indeed the only $\mathrm{N}$-glycosylation acceptor site and is therefore responsible for the slower migration of the wild-type THTR-1 protein. These results indicate that the wild-type THTR-1 protein undergoes $\mathrm{N}$-glycosylation, whereas the G172D mutant undergoes only the initial stage of glycosylation, presumably forming the high mannose $N$-glycan that adds $\sim 2 \mathrm{kDa}$ to the protein electrophoretic mobility (24).

\section{Multiple Amino Acid Substitutions of Glycine 172}

To characterize the role of the specific amino acid present at position 172 (i.e., glycine), we used degenerate oligonucleotides to replace glycine 172 by various amino acids. In all amino acid substitutions shown except for isoleucine, the resultant mutant THTR-1 protein was absent at $37^{\circ} \mathrm{C}$ (data not shown) and was variably expressed at $28^{\circ} \mathrm{C}$ (Fig. 3 ). Furthermore, substitutions with either threonine or methionine were not detectable at $37^{\circ} \mathrm{C}$ or $28^{\circ} \mathrm{C}$ (Fig. 3). All the other amino acid substitutions resulted in both low expression levels and incomplete glycosylation as compared with the wild-type THTR-1 protein (Fig. 3). Similar to the G172D sub- stitution, the initial stage of $\mathrm{N}$-glycosylation occurred in all the G172 substitutions (excluding Thr and Met), resulting in a slight decrease in the electrophoretic mobility of the THTR-1 protein (Fig. 3).

Interestingly, the inability to undergo a complete $\mathrm{N}$-glycosylation, as compared with the wild-type THTR-1 protein, was independent of the specific amino acid side chain introduced; both negatively charged residues such as glutamate and positively charged amino acids like lysine, resulted in a similar pattern of expression and partial $\mathrm{N}$-glycosylation. Moreover, even conservative substitutions such as alanine and valine exhibited a mutant phenotype with incomplete glycosylation. Only isoleucine substitution exhibited a low level of an apparently fully glycosylated THTR-1 protein (Fig. 3 lane 8).

Glycine 172 is located in the middle of putative transmembrane domain number 5 (TMD5) of the human THTR-1 (12). This glycine residue is absolutely conserved in human and mouse THTR-1 and THTR-2 (Table 1B). Thus, it is conceivable that the $\alpha$-helical structure of putative TMD5 is highly conserved such that even small changes in bulk and net charge may disrupt its correct folding, leading to rapid degradation.

\section{THTR-1 Membrane Localization}

Western blot analysis with cell extracts derived from Swiss 3T3 cells transfected with expression plasmids encoding for either the wild-type or the mutant G172D THTR-1, exhibit identical expression patterns as compared with NIH3T3 cells (Fig. 2D). To determine whether $\mathrm{N}$-glycosylation plays a role in the plasma membrane localization of THTR-1, we performed immunofluorescence analysis with transfected Swiss $3 T 3$ cells. Swiss 3T3 cells are larger in size and exhibit distinct cell morphology as compared with NIH 3 T3 cells. Cells were cotransfected with both THTR-1 and green fluorescent protein (GFP) expression plasmids (Fig. 4).

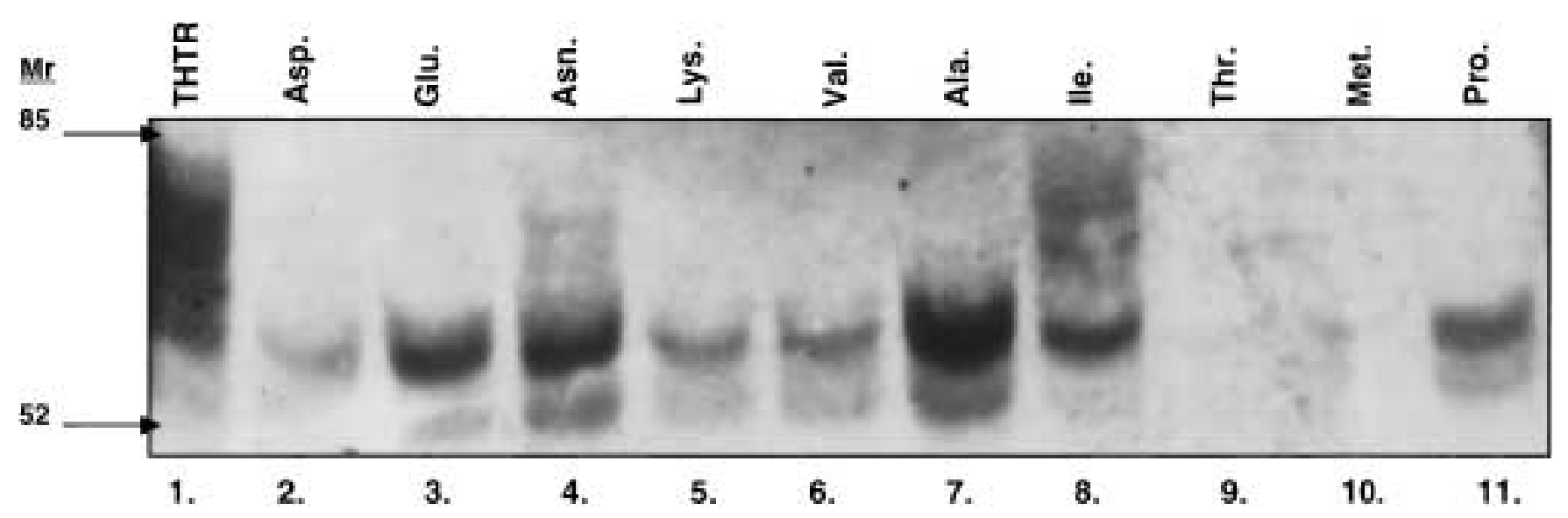

Fig. 3. Multiple amino acid substitutions of the THTR-1 at position 172. NIH3T3 cells were transfected with pCan expression plasmids encoding for THTR-1 mutants as indicated by the three-letter code amino acid substitutions at residue 172. Proteins from cell lysates were resolved on a 10\% SDS-PAGE followed by Western blotting with anti-myc 9E11 monoclonal antibody and antimouse IgG conjugated to HRP (Santa Cruz Inc.) followed by chemiluminescence detection. 

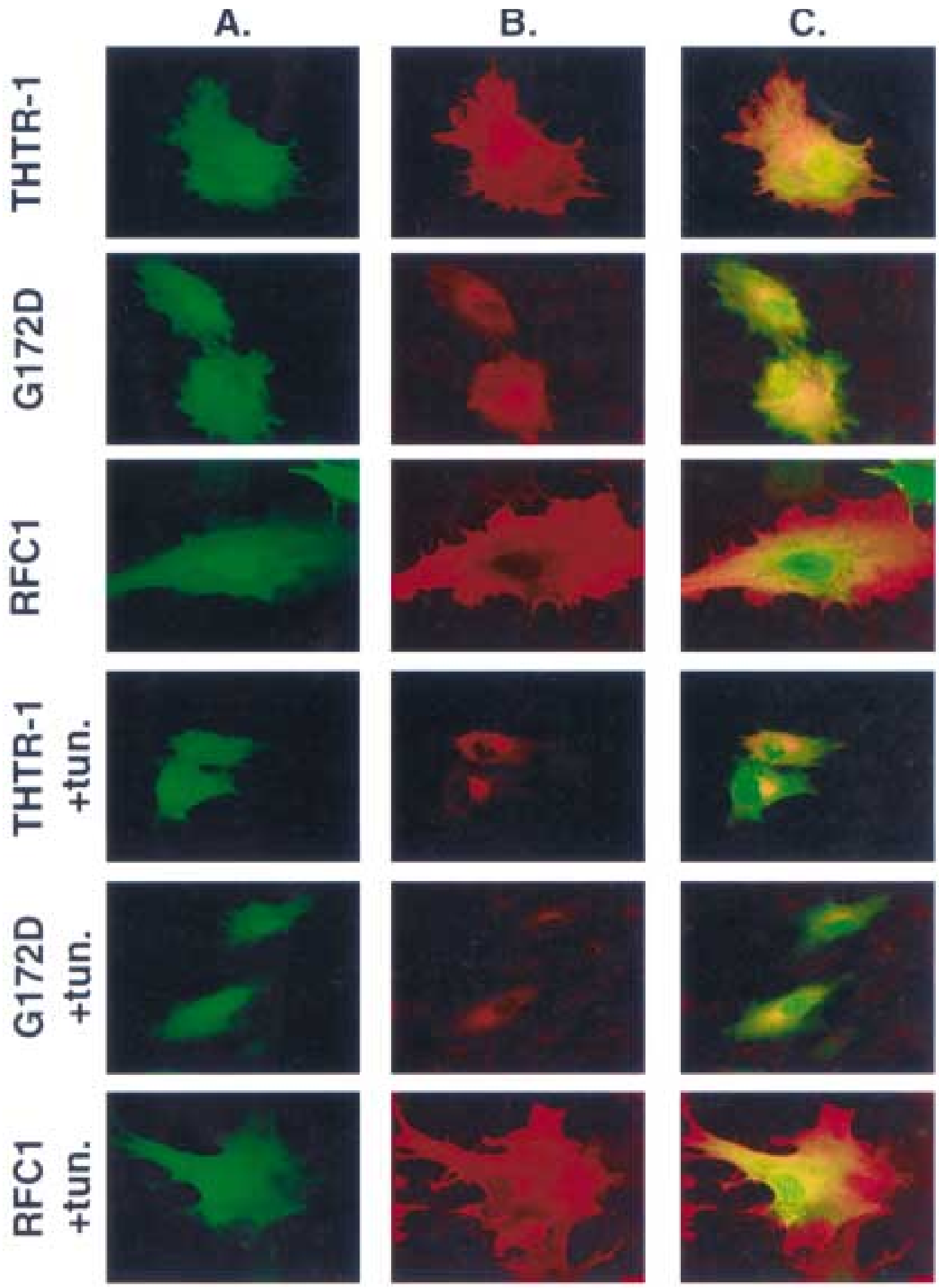

Fig. 4. Cellular localization of wild-type THTR-1 and mutant G172D THTR-1. Swiss 3 T3 cells were cotransfected with GFP expression plasmid either with the Myc-THTR-1 expression plasmids as indicated, or with the pcDNA-RFC-HA expression plasmid. Cells were treated (where indicated) with $10 \mu \mathrm{g} / \mathrm{ml}$ tunicamycin for $24 \mathrm{hr}$ prior to cell fixation and staining with anti-Myc 9E11 monoclonal antibody for myc-THTR-1 or anti-HA monoclonal antibody 12CA5 for RFC-HA and secondary goat anti-mouse CY3 antibody. Cells were then analyzed using confocal microscopy. The localization of GFP alone (green, panel A) or CY3-conjugated goat antimouse antibody staining alone (red, panel B) and costaining (yellow, panel C) is shown. Yellow stain indicates colocalization. Cell transfections and treatments are as indicated: Wild-type THTR-1 (THTR), mutant G172D THTR-1 (GI72D), and RFC-HA (RFC) either untreated or tunicamycin $(10 \mu \mathrm{g} / \mathrm{ml})$ treated cells (+tun.). 
The GFP expression plasmid is expected to cosegregate with the THTR-1 expression plasmid and therefore, cells displaying green fluorescence served in the identification of THTR-1 expressing cells (Fig. 4, panel A). Due to the lack of expression and staining of the mutant G172D THTR-1 protein at $37^{\circ} \mathrm{C}$, cells were cultured at $28^{\circ} \mathrm{C}$ following cell transfection. The staining patterns with either anti-Myc 9E11 monoclonal antibody (THTR-1) or anti-HA 12CA5 monoclonal antibodies (RFC) followed by CY3conjugated goat anti-mouse IgG are shown in panel $\mathrm{B}$ (red fluorescence), and the costaining with both green and red fluorescence is shown in panel $\mathrm{C}$ (yellow fluorescence).

Cells transfected with the wild-type THTR-1 exhibit a perinuclear-endoplasmic reticulum (ER), cytoplasmic as well as plasma membrane staining (Fig. 4, THTR-1 A-C). The immunofluorescence analysis performed with the G172D mutant THTR-1 also displayed an ER and cytoplasmic staining, but no staining could be detected at the plasma membrane (Fig. 4 G172D, A-C). Immunofluorescence analysis of cells transfected with the RFC-HA construct (a close relative of THTR-1 protein) with anti-HA antibody revealed an intense RFC staining at the plasma membrane (Fig. 4 RFC, A-C) as previously observed (22).

To test whether the glycosylation per se plays a role in plasma membrane localization of THTR-1, we treated wild-type THTR-1-transfected cells with the well-established $N$-linked glycosylation inhibitor, tunicamycin $(10 \mu \mathrm{g} / \mathrm{ml})$ for $24 \mathrm{hr}$. Tunicamycin treatment resulted in the lack of plasma membrane targeting of THTR-1 and a confined staining pattern to the perinuclear ER membranes (Fig. 4 A-C, THTR-1 + tun.). Consistently, the staining of tunicamycin-treated mutant G172D THTR-1- transfected cells also revealed a confined localization of the mutant protein to the ER compartment (Fig. 4 A-C, G172D + tun.). These results establish that the $\mathrm{N}$-glycosylation of the human THTR-1 is absolutely essential for its targeting to the plasma membrane. Furthermore, the incompletely glycosylated G172D mutant THTR-1 is retained in the ER and is not targeted to the plasma membrane.

In contrast, treatment of RFC-transfected cells with tunicamycin did not interfere with the plasma membrane localization of RFC (Fig. 4 A-C, RFC + tun.).

To examine the role of $N$-glycosylation to THTR-1 plasma membrane localization more directly, we used the mutant N63Q THTR-1, in which asparagine 63 is substituted with glutamine. This mutant exhibits a complete loss of $N$-glycosylation (Fig. 2C). Indeed, the localization of the THTR-1 N63Q is found to be identical to the pattern obtained with either mutant G172D THTR-1- or tunicamycin-treated wild-type THTR-1, thus strongly suggesting the absolute requirement for THTR-1 $N$-glycosylation for its membrane targeting (Fig. 5).

To define more precisely the localization of the unglycosylated THTR-1 wild-type protein (following tunicamycin treatment), cells were costained with a polyclonal antibody directed against $\beta$-cop, a Golgi-resident protein (26), together with the anti-myc 9E11 monoclonal antibody followed by secondary antibody-conjugated to CY3 (Fig. 6B, red fluorescence) and CY5 (Fig. 6C, blue fluorescence) anti-rabbit and -mouse, respectively (Fig. 6). This analysis showed that wild-type THTR-1 fluorescence (Fig. 6B) was present in the ER, Golgi, and plasma membrane. In contrast, the $\beta$-cop staining (Fig. 6C) was exclusively confined to the Golgi complex. Colocalization of the green (GFP), red (THTR-1), and blue ( $\beta$-cop) fluorescence for the wild-type THTR-1 revealed a pattern of ER, Golgi, and plasma membrane localization (Fig. 6D).
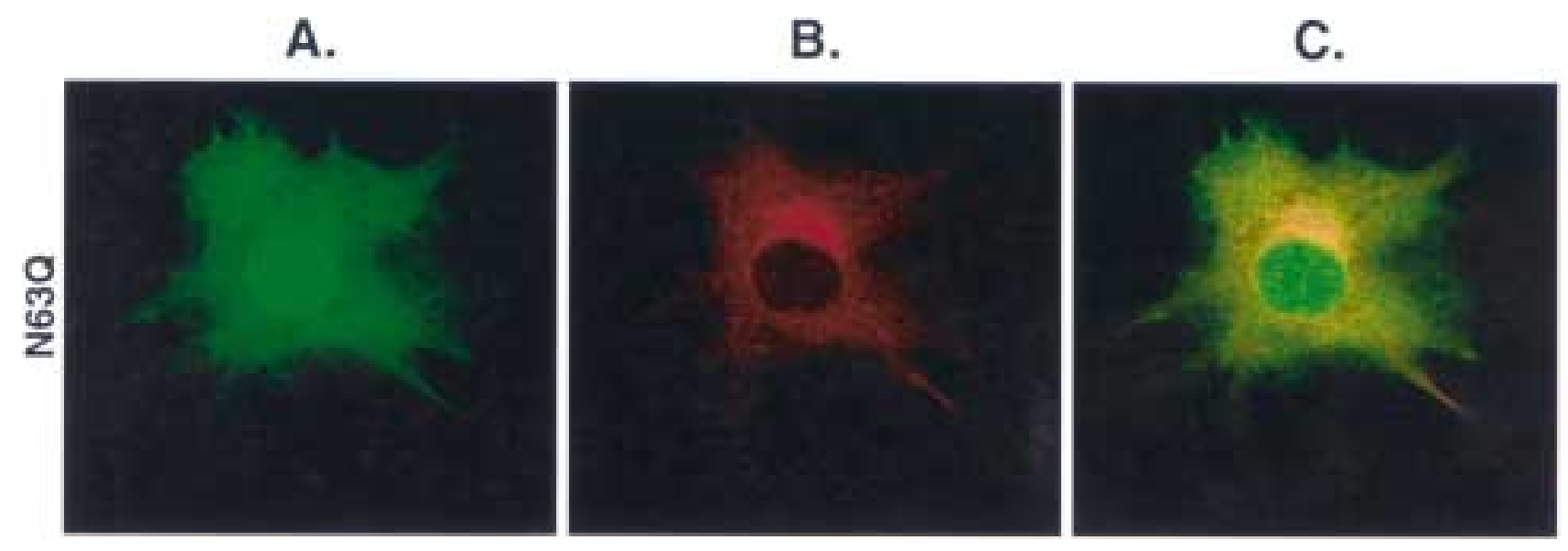

Fig. 5. Cellular localization of an $\mathbf{N - g l y c o s y l a t i o n ~ d e f i c i e n t ~ N 6 3 Q ~ m u t a n t ~ T H T R - 1 , ~ N 6 3 Q . ~ ( A ) ~ S w i s s ~} 3 T 3$ cells were cotransfected with both GFP and THTR-1 N63Q mutant expression plasmids. Transfected cells were fixed and stained with anti-Myc 9E11 antibodies. The localization of GFP alone (green, panel A) or CY3-conjugated goat anti-mouse antibody staining alone (red, panel B) and costaining (panel $\mathrm{C}$ ) is shown. Yellow stain indicates colocalization of the green and red fluorescence. 

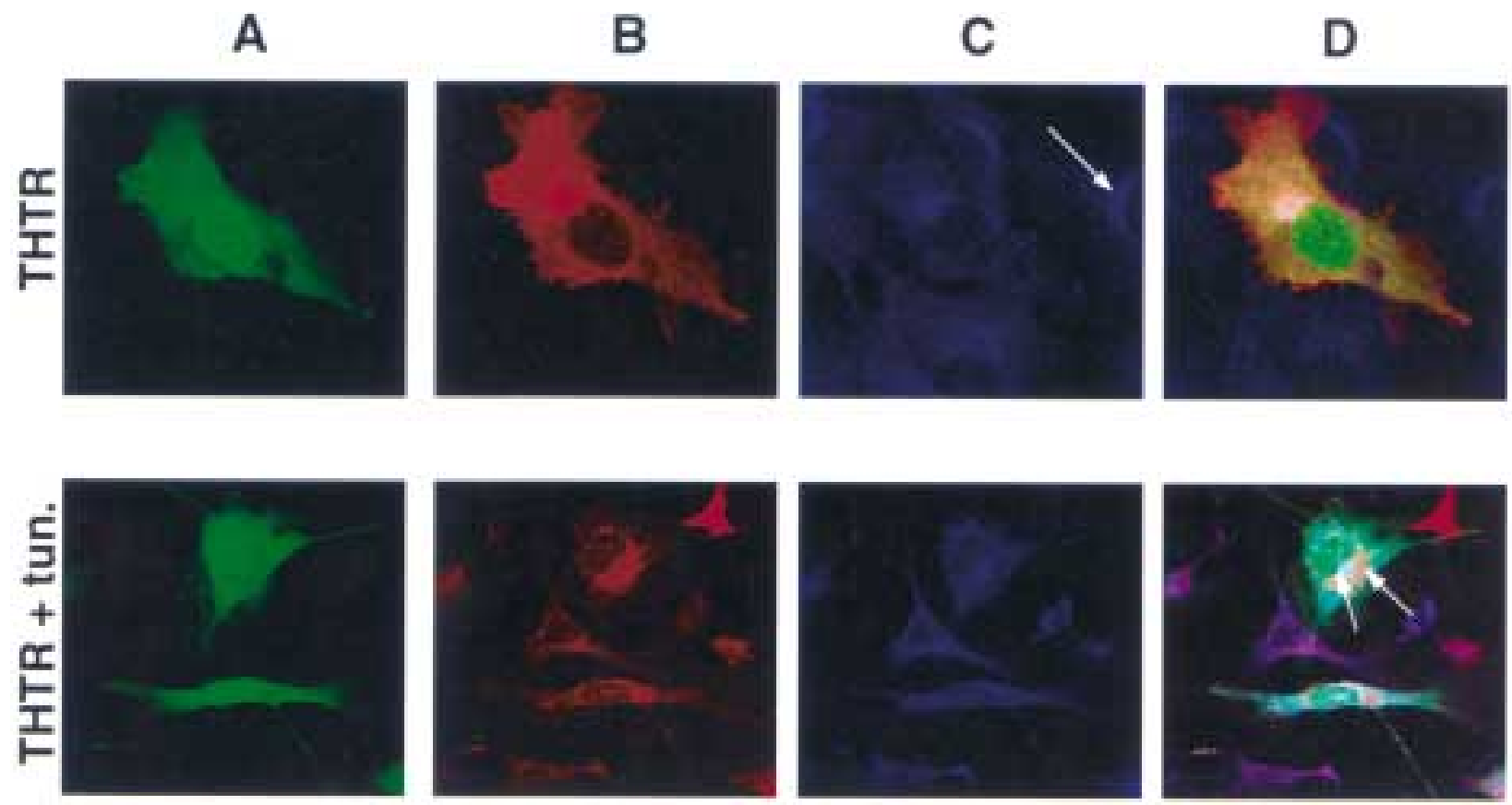

Fig. 6. Cellular colocalization of glycosylated and unglycosylated THTR-1 protein with $\boldsymbol{\beta}$-cop protein. Swiss 3 T3 cells were cotransfected with GFP expression plasmid, together with THTR-1 wild-type expression plasmid, and either left untreated or treated with tunicamycin $(10 \mu \mathrm{g} / \mathrm{ml})$ for $24 \mathrm{hr}$ prior to cell fixation. Cells were stained with anti-myc 9E1l monoclonal antibody and anti- $\beta$-cop rabbit polyclonal antibody. The following panels are shown: GFP stain (green, panel A), myc-THTR-1 stain using CY3 conjugated goat anti-mouse (red, panel B), $\beta$-cop stain using CY5 conjugated goat anti-rabbit (blue, panel C). The white arrow at the top panel in $C$ indicates the staining of the Golgi compartment. The convergence of all three filters is shown in panel D. The white arrows at the bottom panel in D indicate the staining of the Golgi (left) and ER (right) compartments.

In contrast, following tunicamycin treatment, THTR-1 fluorescence was highly confined to the ER with no localization at the plasma membrane (Fig. 6B THTR + Tun.). Furthermore, although $\beta$-cop staining was confined to the Golgi complex, colocalization of the green (GFP), red (tunicamycin-treated THTR), and blue fluorescence $(\beta$ cop) showed a predominant confinement to the ER with very little localization at the Golgi (Fig. 6 panel D). Similar colocalization results were obtained with mutant G172D THTR-1 (data not shown). These results suggest that both the unglycosylated THTR-1 after tunicamycin treatment and the incompletely glycosylated mutant G172D THTR-1 proteins are predominantly retained in the ER and are not translocated to the Golgi and, therefore, fail to be transferred to the plasma membrane.

\section{Thiamine Transport in Cells Stably Expressing Wild-Type and Mutant G172D THTR-1}

The thiamine transport function of the wild-type and G172D mutant THTR-1 proteins was examined in Swiss 3T3 cells infected with retroviruses expressing the corresponding proteins. Puromycinresistant cells were selected and thiamine uptake was determined after $20 \mathrm{~min}$ of incubation at $37^{\circ} \mathrm{C}$ as described in (5). Cells expressing wild-type THTR-1 protein displayed a 2 -fold higher thiamine uptake as compared to control Swiss 3T3 cells (Fig. 7). This result indicates the functionality of the THTR-1 protein constructed and that the fusion of the $\mathrm{N}$-terminally myc epitope tag did not impair thiamine transport activity. In addition, these results are in complete agreement with previous reports describing the thiamine uptake of cells transfected with either THTR-1 $(5,27)$ or THTR-2 $(6)$. In contrast, Swiss 3T3 cells expressing the mutant G172D THTR-1 did not have any increase in the uptake of $\left[{ }^{3} \mathrm{H}\right]$-thiamine. These results further establish the inability of mutant G172D THTR-1-transfected cells to take up thiamine beyond their basal uptake levels.

\section{Discussion}

Molecular Basis for Rogers Syndrome

Patients carrying mutations in the THTR-1 gene suffer from a lack of the vitamin thiamine. This vitamin deficiency can be partially overcome by administration of megadoses of thiamine (28). Similar manifestations of the disease are observed in patients harboring different mutations in the THTR-1 gene. This suggests that either missense or nonsense/frame-shift mutations may result in a similar lack of transporter function (18). Indeed, no THTR-1 protein is detected following expression of the mutant G172D THTR-1 in mouse NIH 3T3 (Fig. 1) and Swiss 3T3 cells (not shown) grown at 


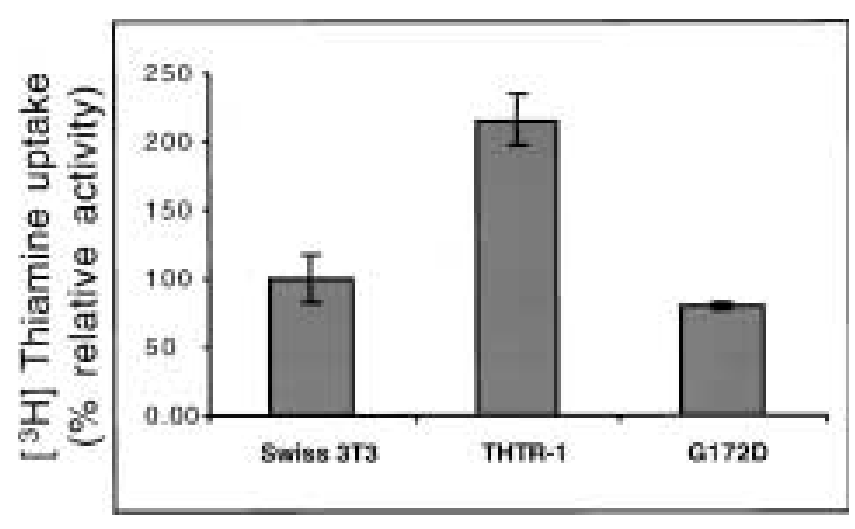

Fig. 7. $\left[{ }^{3} \mathrm{H}\right]-$ Thiamine uptake in Swiss $3 T 3$ cells transfectants expressing the wild-type and mutant G172D THTR-1 proteins. $\left[{ }^{3} \mathrm{H}\right]$-Thiamine uptake was measured in Swiss 3T3 cells ectopically expressing the indicated proteins. Net thiamine uptake was calculated by subtraction of the radioactivity obtained at $37^{\circ} \mathrm{C}$ with that observed at $4^{\circ} \mathrm{C}$. Net thiamine uptake in parental Swiss $3 \mathrm{~T} 3$ cells was determined as $100 \%$, whereas wild-type and G172D mutant THTR-1 expressing cells were calculated relatively. The $100 \%$ thiamine uptake of Swiss 3T3 cells corresponds to an average of 192 pmols $/ 10^{6}$ cells $/ 20 \mathrm{~min}$. Results shown represent the average and standard error of the mean derived from three independent experiments. The cells were incubated with $\left[{ }^{3} \mathrm{H}\right]$-thiamine for $20 \mathrm{~min}$ in a transport buffer at pH 7.9 as described in materials and methods.

$37^{\circ} \mathrm{C}$. In contrast, at a lower temperature $\left(28^{\circ} \mathrm{C}\right)$, the mutant G172D protein is found at detectable levels and could be used for further biochemical and functional analysis. The molecular mechanism underlying the accumulation of the protein at the lower temperature is not known. One possibility may be that, at $28^{\circ} \mathrm{C}$, the protein is less amenable to degradation.

\section{Intracellular Trafficking}

Although at the permissive temperature the mutant G172D THTR-1 protein is expressed at lower but detectable levels as compared with the wild-type THTR-1 protein, the mutant G172D protein fails to undergo a complete posttranslational modification reflected in the lack of a complete $N$-linked glycosylation. The failure to undergo a complete glycosylation was accompanied by the inability to target the protein to the plasma membrane. Similarly, the use of tunicamycin to block $N$-linked glycosylation resulted in the retention of the wild-type THTR-1 protein in the ER and lack of its targeting to the plasma membrane. More directly, disruption of the $N$-glycosylation consensus site within THTR-1 by site-directed mutagenesis, strongly indicates the absolute $N$-glycosylation requirement of THTR-1 for its proper plasma membrane localization. This is in contradistinction to the results observed with another close member of the solute carrier family, the human RFCl, that does not require glycosylation for its plasma membrane localization (Fig. 4) (22). This is in accord with the fact that the mouse RFC does not contain any consensus $\mathrm{N}$-glycosylation site (Table lA) but nevertheless, is efficiently targeted to the plasma membrane (22). RFC is one of the exceptions to the rule; for the vast majority of the integral plasma membrane proteins, glycosylation was found to be absolutely crucial for their proper plasma membrane localization (24). In THTR-1, asparagine-63 is the acceptor for the $N$-glycan part and is conserved across species as opposed to asparagine 314 and 413 that are not conserved among different species (Table 1). In addition, these sites are located within the putative transmembrane domains 7 and 10 , respectively, and presumably are not accessible for $N$-glycosylation. This strongly indicates the crucial role of asparagine 63 for THTR-1 N-glycosylation. Based on this analysis (Table 1A), one could predict that the third member of the solute carrier family, THTR-2, may also require an $N$-linked glycosylation for proper plasma membrane targeting.

Within the chloride $\left(\mathrm{Cl}^{-}\right)$conductance regulator (CFTR) deletion of phenylalanine 508 is the most common mutation found in cystic fibrosis. This mutation results in the expression of a nonfunctional protein. However, when cells are grown at a lower temperature $\left(28^{\circ} \mathrm{C}\right)$, channel activity measured as $\mathrm{Cl}^{-}$conductance is restored (25). In CFTR, the glycosylation per se does not affect localization or function but rather serves as a marker for protein processing (25), whereas in the THTR-1 protein, we demonstrate that $N$-linked glycosylation is absolutely required for the plasma membrane localization.

\section{Protein Folding Quality Control Mechanism}

It is well established that the ER possesses a quality control system scrutinizing the proper folding of newly synthesized proteins. This mechanism prevents mutant and/or misfolded proteins from undergoing further processing and trafficking. Consequently, the unmodified proteins would either accumulate in the ER and be degraded therein, or would be translocated out of the ER to lysosomes, in which they undergo degradation $(29,30)$. A similar complex quality control process was found for the CFTR protein (31). Thus, the G172D mutation predicted to reside within putative TMD5 of the THTR-1 is likely to lead to a misfolded protein, consequently resulting in the lack of complete $N$-linked glycosylation leading to the lack of targeting to the plasma membrane. Even at the lower temperature, the mutant protein fails to be properly glycosylated. Conversely, the expression of the multidrug resistant transporter, $\mathrm{P}$-glycoprotein, at lower temperatures results in the complete processing of the mutant protein (32).

One possible mechanism for the quality control process could be either by direct or indirect recognition of protein chaperons such as hsp70 and calnexin (33). Indeed, calnexin was found to be involved in the processing of CFTR and P-glycoprotein, and thus takes an active part in the quality control process. Calnexin was found to be associated with both wild-type 
and mutant unprocessed proteins in the ER, but only the mature, fully processed proteins were able to escape from this association and exit the ER $(32,33)$.

The initial step in of $N$-glycosylation is the attachment of glucose-mannose- $N$-acetylglucosamine oligosaccharide to the acceptor asparagine residue. This process occurs at the lumen of the ER and is independent of protein folding (24). Consistently, the mutant G172D THTR-1 protein appears to undergo the initial step of $\mathrm{N}$-glycosylation in which presumably, the high mannose oligosaccharide $(\sim 2 \mathrm{kDa})$ is attached to asparagine 63. This is supported by several lines of evidence: (a) mutant G172D THTR-1 protein gains only $\sim 2 \mathrm{kDa}$. (b) Upon SDS-PAGE, this oligosaccharide can be cleaved enzymatically with $N$-glycosidase F (PNGase F). (c) the established $\mathrm{N}$-glycosylation inhibitor, tunicamycin, abolishes THTR-1 glycosylation. (d) substitution of asparagine 63 by glutamine disrupts the $N$-linked glycosylation. The final step of glycosylation takes place en route during the translocation of the glycoprotein from the ER to the Golgi apparatus to its final destination, the plasma membrane. This process is absolutely dependent on prior acquisition of proper folding. Whereas the mutant G172D THTR-1 protein is not completely glycosylated, we propose that it is not properly folded, and therefore is unable to escape the ER and is consequently subjected to degradation.

Kyte-Doolitle hydropathy analysis of the glycine residue at position 172 is predicted to reside within putative TMD5 of THTR-1 (4). THTR-1 TMD5 is highly conserved with THTR-2 but to lesser extent with RFC (Table 1B). Indeed, we found that this position is very sensitive to amino acid substitutions; almost any amino acid change resulted in defective post-translational processing. This may indicate that this hydrophobic $\alpha$-helical region is highly structured, and even conservative substitutions such as alanine or valine may lead to a strong perturbation in the proper folding of this transmembrane domain. Although Gly 172Ile exhibited partially glycosylated THTR-1, the absolute levels were very low when compared to the parental THTR-1 transporter. Consequently, immunofluorescence studies failed to detect Gly172Ile in the plasma membrane.

An apparently fully glycosylated mature wildtype THTR-1 protein could be observed at $28^{\circ} \mathrm{C}$, albeit to a much lesser extent compared to the wild-type THTR-1 at $37^{\circ} \mathrm{C}$. Inactivating mutations of many transporters frequently occur at various transmembrane domains, for example, in the human (34), mouse RFCl (35), and P-glycoprotein (32). The THTR-1 missense mutations G172D and S143F are predicted to reside in putative TMD5 and TMD4, respectively, whereas the missense mutant $\mathrm{D} 93 \mathrm{H}$ THTR-1 maps to putative intracellular loop 2 connecting putative TMD2 and TMD3 $(4,12)$. Preliminary analysis of the latter mutation suggests that the molecular basis for Rogers syndrome in this D93H
TRMA patient is not associated with the lack of plasma membrane targeting but a functional defect in thiamine transport (Baron, D., Assaraf, Y.G., Aronheim A., unpublished data).

Previous studies have demonstrated the lack of thiamine transport in TRMA patients (10). In view of our results, TRMA patients carrying the G172D mutation cannot exhibit active thiamine transport due to the fact that the mutant G172D THTR-1 protein is absent from the plasma membrane. Indeed, we find that Swiss 3T3 transfectant expressing G172D mutant THTR-1 protein display comparable thiamine uptake with the basal uptake of the parental cells, whereas wild-type expressing cells exhibit a 2 -fold increase in thiamine uptake. Even at lower temperature, where the G172D mutant THTR-1 protein is expressed, thiamine uptake is not expected to occur because the protein is not glycosylated and therefore is not localized to the plasma membrane.

In summary, our findings provide the first molecular basis for the lack of thiamine transport in TRMA patients harboring the G172D mutation. Characterization of the molecular and functional basis of different THTR-1 missense mutations should provide important insights in the understanding of the structure-function relationships of THTR-1 as well as other members of the solute carrier family.

\section{Acknowledgments}

We wish to thank Drs Y. C. Broder and O. Shenkar for technical assistance with cell staining and confocal microscopy, respectively; Ms. A. Cohen for technical assistance; Dr G. Spira for the use of laboratory equipment; Drs V. Labay and D. Kornizer for fruitful suggestions; and Dr L. H. Matherly for the human RFC-HA expression plasmid.

This work was partially supported by the Israeli Academy of Sciences and Juvenile Diabetes International Foundation to N. C. and by Technion internal grants to A. A.

\section{References}

1. Rindi G, Laforenza U. (2000) Thiamine intestinal transport and related issues: recent aspects. Proc. Soc. Exp. Biol. Med. 224: 246-255.

2. Labay V, Raz T, Baron D, et al. (1999)Mutations in SLC19A2 cause thiamine-responsive megaloblastic anemia associated with diabetes mellitus and deafness. Nat. Genet. 22: 300-304.

3. Fleming JC, Tartaglini E, Steinkamp MP, Schorderet DF, Cohen N, Neufeld EJ. (1999) The gene mutated in thiamineresponsive anemia with diabetes and deafness (TRMA) encodes a functional thiamine transporter. Nat. Genet. 22: 305-308.

4. Diaz GA, Banikazemi M, Oishi K, Desnick RJ, Gelb DB. (1999) Mutations in a new gene encoding a thiamine transporter cause thiamine-responsive megaloblastic anemia syndrome. Nat. Genet. 22: 309-312.

5. Dutta B, Huang W, Molero M, et al. (1999) Cloning of the human thiamine transporter, a member of the folate transporter family. J. Biol. Chem. 274: 31925-31929. 
6. Rajgopal A, Edmondnson A, Goldman ID, Zhao R. (2001) SLC19A3 encodes a second thiamine transporter ThTr2. Biochim. Biophys. Acta 1537: 175-178.

7. Casirola D, Patrini C, Ferrari G, Rindi G. (1990) Thiamin transport by human erythrocytes and ghosts. J. Membr. Biol. 118: 11-18.

8. Rogers LE, Porter FS, Sidbury Jr. JB. (1969) Thiamineresponsive megaloblastic anemia. J. Pediatr. 74: 494-504.

9. Mandel H, Berant M, Hazani A, Naveh Y. (1984) Thiaminedependent beriberi in the "thiamine-responsive anemia syndrome." N. Engl. J. Med. 311: 836-838.

10. Rindi G, Patrini C, Laforenza U, et al. (1994) Further studies on erythrocyte thiamin transport and phosphorylation in seven patients with thiamin-responsive megaloblastic anemia. J. Inherit. Metab. Dis. 17: 667-677.

11. Abboud MR, Alexander D, Najjar SS. (1985) Diabetes mellitus, thiamine-dependent megaloblastic anemia, and sensorineural deafness associated with deficient alpha-ketoglutarate dehydrogenase activity. J. Pediatr. 107: 537-541.

12. Eudy JD, Spiegelstein O, Barber RC, Wlodarczyk BJ, Talbot J, Finnell RH. (2000) Identification and characterization of the human and mouse SLC19A3 gene: a novel member of the reduced folate family of micronutrient transporter genes. Mol. Genet. Metab. 71: 581-590.

13. Dixon KH, Lanpher BC, Chiu J, Kelley K, Cowan KH. (1994) A novel cDNA restores reduced folate carrier activity and methotrexate sensitivity to transport deficient cells. J. Biol. Chem. 269: 17-20.

14. Prasad PD, Ramamoorthy S, Leibach FH, Ganapathy V. (1995) Molecular cloning of the human placental folate transporter. Biochem. Biophys. Res. Commun. 206: 681-687.

15. Wong SC, Proefke SA, Bhushan A, Matherly LH. (1995) Isolation of human cDNAs that restore methotrexate sensitivity and reduced folate carrier activity in methotrexate transport-defective Chinese hamster ovary cells. J. Biol. Chem. 270: 17468-17475.

16. Jansen G, Pieters R. (1998) The role of impaired transport in (pre)clinical resistance to methotrexate-insights on new antifolates. Drug Resistance Updates 1: 211-218.

17. Lo PK, Chen JY, Tang PP, et al. (2001) Identification of a mouse thiamine transporter gene as a direct transcriptional target for p53. J. Biol. Chem. 276: 37186-37193.

18. Raz T, Labay V, Baron D, et al. (2000) The spectrum of mutations, including four novel ones, in the thiamine-responsive megaloblastic anemia gene SLC19A2 of eight families. Hum. Mutat. 16: 37-42.

19. Stagg AR, Fleming JC, Baker MA, Sakamoto M, Cohen N, Neufeld EJ. (1999) Defective high-affinity thiamine transporter leads to cell death in thiamine-responsive megaloblastic anemia syndrome fibroblasts. J. Clin. Invest. 103: 723-729.

20. Naviaux RK, Costanzi E, Haas M, Verma IM. (1996) The pCL vector system: rapid production of helper-free, high-titer, recombinant retroviruses. J. Virol. 70: 57015705.

21. Hibi M, Lin A, Smeal T, Minden A, Karin M. (1993) Identification of an oncoprotein and UV responsive kinase that binds and potentiates the activity of the c-jun activation domain. Genes Dev. 7: 2135-2148.

22. Wong SC, Zhang L, Proefke SA, Matherly LH. (1998) Effects of the loss of capacity for N-glycosylation on the transport activity and cellular localization of the human reduced folate carrier. Biochim. Biophys. Acta 1375: 6-12.

23. Sharif KA, Goldman ID. (2000) Rapid determination of membrane transport parameters in adherent cells. Biotechniques $\mathbf{2 8}$ 926-928, 930, 932.

24. Gahmberg CG, Tolvanen M. (1996) Why mammalian cell surface proteins are glycoproteins. Trends Biochem. Sci. 21: 308-311.

25. Denning GM, Anderson MP, Amara JF, Marshall J, Smith AE, Welsh MJ. (1992) Processing of mutant cystic fibrosis transmembrane conductance regulator is temperaturesensitive. Nature 358: 761-764.

26. Featherstone C. (1998) Coming to grips with the Golgi. Science 282: 2172-2174.

27. Fleming JC, Steinkamp MP, Kawatsuji R, et al. (2001) Characterization of a murine high-affinity thiamine transporter, Slc19a2. Mol. Genet. Metab. 74: 273-280.

28. Valerio G, Franzese A, Poggi V, Tenore A. (1998) Long-term follow-up of diabetes in two patients with thiamine-responsive megaloblastic anemia syndrome. Diabetes Care 21: 38-41.

29. Klausner RD, Sitia R. (1990) Protein degradation in the endoplasmic reticulum. Cell 62: 611-614.

30. Verma R, Deshaies RJ. (2000) A proteasome howdunit: the case of the missing signal. Cell 101: 341-344.

31. Jensen TJ, Loo MA, Pind S, Williams DB, Goldberg AL, Riordan JR. (1995) Multiple proteolytic systems, including the proteasome, contribute to CFTR processing. Cell 83: 129-135.

32. Loo TW, Clarke DM. (1994) Prolonged association of temperature-sensitive mutants of human P-glycoprotein with calnexin during biogenesis. J. Biol. Chem. 269: 2868328689.

33. Pind S, Riordan JR, Williams DB. (1994) Participation of the endoplasmic reticulum chaperone calnexin (p88, IP90) in the biogenesis of the cystic fibrosis transmembrane conductance regulator. J. Biol. Chem. 269: 12784-12788.

34. Drori S, Jansen G, Mauritz R, Peters GJ, Assaraf YG. (2000) Clustering of mutations in the first transmembrane domain of the human reduced folate carrier in GW1843U89-resistant leukemia cells with impaired antifolate transport and augmented folate uptake. J. Biol. Chem. 275: 30855-30863.

35. Zhao R, Sharina IG, Goldman ID. (1999) Pattern of mutations that results in loss of reduced folate carrier function under antifolate selective pressure augmented by chemical mutagenesis. Mol. Pharmacol. 56: 68-76. 